\title{
HAS HOMO ECONOMICUS NATIONALITY?
}

\begin{abstract}
Contrary to a common presentation of economic person in a simple market economy as homo economicus, people often express non-standard types of rationality, not to mention the irrationality, emotionality, altruism, communal and membership-seeking impulses via consumption choices and so on. And although in economic theory the rationality of the behavior of homo economicus is viewed in a different way from rationality in everyday life, a question arises: can real people be interpreted as - more or less - economic persons or have they nationality outside the pictured theoretical land - terra economicus. As to national specificity, it is superimposed on genetics: on the whole, Western civilizations with their inherent two-valued logic of thinking are more prone to economic exchanges - transactions, while Eastern civilizations, with their multi-valued logic - to social exchange processes - interactions. At the same time real people in West in certain circumstances may prefer social markets to economic ones and people in the East can give preference to economic markets over the social ones. Such demarcation is rather conditional as well as putting forward conditional and rather provocative question of nationality of homo economicus.

Keywords: homo economicus, non-economic factors, national specificity.

JEL Classification: A12, B40, D21, M12, M14, O15, P00, Z10.
\end{abstract}

\section{INTRODUCTION}

In her paper titled "Russian Semiotics of Behavior, or Can a Russian Person be Regarded as 'Homo Economicus'?" Natalia Vinokurova while discussing the idea of the homo economicus, or economic person's existence put forward, rather implicitly than explicitly, another important idea - let us call it the idea of the economic person's nationally (that is: not rationality, but nationality).

An economic person known in orthodoxy as homo economicus can deal more or less successfully with / in what could be called 'hardware' of economy, i.e. industry and agriculture. However, when dealing with more subtle subjects, such as institutions and non-material things, which could be coined as 'software' of economic activity, the useful and fruitful concept of homo economicus failes. Such situation "associated with culture, science and factors like co-operation, communication, consciousness and memory that constitute the generalized interaction" (Kapitza, 2006, p. 191) may be called as 'homo economicus failure'. As writes Sergey Kapitza, "after Max Weber and Josef Schumpeter, it is now acknowledged that 'software' is becoming the primary factor in development. Their ideas suggest that information is not a minor macroeconomic component, but controlling factor in the metaeconomics of a knowledge society" (ibid.).

Studying the Russian semiotics of behavior, Natalia Vinokurova (2016) inquires: can a Russian person be regarded as homo economicus. Certainly, it is impossible not to agree with that in theory and reality persons as to their rationality behave differently: "In economic theory the rationality of the behavior of the homo economicus os viewed in a dif- 
ferent way from rationality in everyday life. It is not simply reasonableness or common sense. Economic rationality is the ability to make an optimal choice, i.e. a chpice that maximizes one's own gains, while being constrained by certain conditions. Moreover, this supposition applies to behavior of any economic subject, whether an individual, enterprise, company or other each of them aspires to receive maximum profits" (Vinokurova, 2016, p. 134).

And although real people and their modeled types are not the same, one can ask, whether real persons are closer to one or another type of homo - be he or she - economicus (fully rational), boundedly rational, irrational, emotional and so on.

Let us modify the abovementioned question: can a person of whatever nationality be regarded as homo economicus? Does in general homo economicus possess nationality?

\section{RUSSIAN DISCUSSIONS OF THE CONCEPT OF HOMO ECONOMICUS}

Discussions on the topic of homo economicus have been ongoing in Russia for a long time. So, at the turn of the $19^{\text {th }}-20^{\text {th }}$ centuries, the concept was studied from the perspective of economic, social, philosophical and religious point of views. For example, Sergii Bulgakov "tried to subject political economy to the ethical principles of Christianity. He reacted with great interest to the ideas of Weber, notably to his appraisal of the meaning of religion for the development of the economy, and to his proposition in his 'Protestant ethic' of moral justofocation for aspiration to wealth" (Vinokurova, 2016, p. 135).

It is noteworthy that Bulgakov's emphasis was not on personal, but on national wealth. This has something in common with what Dmitry Lvov said a hundred years later that either everyone or no one would be saved.

Let us now present some characteristic features inherent in the modern Russian discussions of the homo economicus concept (Vinokurova, 2016, p.155-156).

1. Emotionalism and tendency to resort to personal comments especially in journalistic discourse and some scholarly works.

2. Emphasis on that part of the definition of the homo economicus that underlines the person's interest in material gain and the desire for wealth.

3. The comparison between Russia and the West, between Russians and Western people.

4. Attempts to link material wealth with soullessness and immortality.

5. Attempts to link the problem of economic behavior with a broader theme - behavior as moral or immoral, the issue of justice ans injustice, especially in works of: Dmitry Lvov, Valery Makarov, Sergei Glaziev, Viktor Dementiev, Bagrat Yerznkyan.

6. Striving to search for an ideal which would not be connected to consumerism in any of its manifestations. 


\section{ADDING SOCIAL CONTEXT}

Accounting social factors is necessary to catch the very sense of socio-economic reality and to model it adequately. The success of modern economy predominantly depends on the continuity of innovation, continuity of technological revolutions that change the structural characteristics of the socio-economic relations.

According to V.L.Makarov, "profit maximization and utility are suitable only for simple market economy" where there is not, for example, such thing as a desire to go up the social ladder, to obtain a new rank (Makarov, 2010, pp. 191, 199).

S.Yu. Glaziev adds to it ethical factors: "Modern economic science obviously disregards the meaning of ethical values in the formation of economic behavior. The dominating paradigm of market balance is based on an assumption of the rational behavior of economic agents, directed at the single motive - maximization of profits". Such approach "ignores the meaning of all other motives that influence economic behavior and its moral limits" (Glaziev, 2008, p. 406).

V.E. Dementiev attracts attention to the homo economicus' rationality as primarly associated with a behavior based on self-interest: "altruism and solidarity are clearly absent from the neoclassical portrait of homo economicus where the latter is presented as a hyperrational, exclusively self-interested subject" (Dementiev, 2004, p. 46).

\section{ADDING MORAL CONTEXT}

Form the very beginning of the neo-liberal reforms in Russia for many of prominent scholars became clear that its realization "has fallen far short of what the advocates of the market economy had promised, or hoped for. For the majority of those living in the former Soviet Union, economic life under capitalism has been even worse than the old Communist leaders had said it would be" (Stiglitz, 2002, p. 133).

D. Lvov (1995), as one of these prominent economists, proposed its own reform strategy as a reply to global challenges and being a part of Russian economy's modernization and development project catches at least six aspects:

1) social orientation - the thesis of the archaic character of the state and its discrepancy with market economy conditions can hardly be accepted for the sole reason that this system was introduced in the countries with the highly developed market economy;

2) social-psychological factors - the psychological aspect plays a fundamental role in the complex of measures aimed at overcoming the crisis. Not only the national economy and political institutions must be reconstructed, but also the people's subjective attitude towards the reality;

3) old-new structures correlation - there are many aspects of co-operation of the new and old economic structures; 
4) economy's openness - the thesis of transition to the open economy as such does not evoke objection, however its general concepts do net necessarily mean that all exchanges are usually economically and politically effective and their terms are inessential;

5) privatization, its necessity and consequences - although property is the central question of the economic reforms, in the situation of 1990's Russian reforms it could neither be solved nor correctly formulated;

6) inflation - in 1990s Russia, the true vehicle of inflation was not be excessive money demand but the economic behavior of technologically backward and monopolized producers (Lvov, 1995, pp. 9-18).

As claimed Lvov, in order to begin doing something after reform and post-reform years collapse and thus to catch and stand on the way leading to the favorable future, it should be changed the following positions:

- attitude to the people - they should be supported by their native culture and spirit - the only way to avoid the transmutation of human beings into a physical "labor force" that waits to be exchanged for lifeless animal comforts;

- public revenue distribution system - it includes the returning financial resources to everyone for achieving sustainable economic growth and prosperity for every citizen;

- social conditions - the doubling or tripling of average wages especially in those industries, which should then became a starting norm for other sectors; activation of investment policy; shifting the main tax burden from incomes to people's real estate; declaring the principle of free housing for people on the lowest incomes, free land plots, and other social guarantees;

- distortions - that occurred as a result of the voucher privatization scheme;

- state property system - by creating a system national property and national dividend;

- relation to rent - in a sense that its socialization is both a real opportunity to provide sustainable public revenue and a condition for allowing Russia to remain an independent geopolitical unit and competitive participant in the modern world (Lvov, 2001).

In short, insights of Lvov presented in the abovementioned reform strategy are the best illustration of his central message - to indicate a way to the future for Russia, moreover not only for Russia itself, but also to help other counties, including Eurasian ones, to find their own ways to the future. And the only way out of the tragedy caused by reformers' efforts to copy Western practices and norms ignoring the commonality of interests of the population and giving priority to the cult of individual, was "to build an economy that reflects the common interests of the people and their natural endowments, the organizing mechanism for which would be a restructured public finance" (Harrison, 2001, p. 7), an economy - to be added - based on innovation institutions as an organic part of the emerging national innovation system and at the same time of the developing national institutional system.

As underlines D. Lvov such concepts as "conscience, moral principles and spirituality" have to stand out not as "limiters in economic models, but as criteria for the behavior of 
economic agents". In addition, not sharing the Soviet understanding of collectivism, he nevertheless tracted it as a necessary condition of moral economic theory: "the only path which leads Russia to progress and prosperity is the path of moral economics. Its key aspect is a profoundly personal, individually chosen way towards the sense of the collective, of the community, for Russian collectivism is ideed based on a common task, common ideas and common goals" (Lvov, 2004, p. 38).

\section{ADDING CULTURAL AND INSTITUTIONAL CONTEXTS}

As stated in Yerznkyan (2016, p. 87) despite a long history of writers on the relationship between culture and economy, culture and economic theory, modern mainstream neoclassical in essence - economics has been by and large silent on the topic of culture, on the ideas of the original institutionalists, evolutionary economists, social economists, and other followers of the other canon. However, recently the topic concerning the importance of culture for economic outcomes and the influence of culture on the economic process, take on renewed relevance. It is not surprising that most socially-oriented economists define economics as a cultural science. "Its subject matter is the ever-changing world of economic phenomena that are bound to a very specific cultural context. So explaining economic phenomena requires acknowledging that economic action and thinking are culturally conditioned, which in turn necessitates a procedure that takes seriously the efficacy of the cultural sphere and that does not reduce the cultural sphere to a mere economic residual" (Goldschmidt, Remmele, 2005, p. 465).

Efficiency of managing the socioeconomic development depends largely on the cultural and institutional contexts specificity (Yerznkyan et al., 2017; Yerznkyan, Gassner, 2018). Culture and institutions, regarded from economic perspective, are related concepts especially culture and informal institutional constraints such as codes of conduct, norms of behavior, and conventions, which are, according to North (1990, p. 37), "a part of heritage that we call culture". The importance of the mentioned contexts is regarded on the example of the contemporary Russian corporations which use hybrid agreements and mechanisms of transaction management. Some specific cultural characters of the organizations of inter-firm cooperation in the Russian industrial market and some of Russian-specific cultural factors applying to these organizations revealed by them are studied in (Popov, Simonova, 2015). Culture and institutions may be well enough understood in the language of information transmission "from one generation to the next, via teaching and imitation, of knowledge, values, and other factors that influence behavior" (Boyd, Richerson, 1985, p. 2).

The relevance of culture is of particular importance in reforming the economy. In (Martishin, 2015) it is shown that the strategy of reforms depends on the nature of the economic systems, assuming the measure of the gradual and radical development processes is based on the internal systems of genotypic regularities, which include the conservative and liberal lifestyles, their change and unity. To effectively reform Russia, the Russian genotype mutations, characterized by the excessive dominance of conservatory order, need to be elim- 
inated. This can be done through an evolutionary reform strategy, assuming both the transformation of the old order and the gradual construction of genotypic economic models. Institutional trajectory of modernization should start with the «top» level of the existing features of economic systems and be concluded with the consideration of the general genotypic regularities of the global economic system, which does not deny the cultural and socio-economic features of the countries and regions. See also a paper (Arkhipov et al, 2015), where the authors analyze evolutionary-institutional patterns and factors of economic growth and development on the example of a number of countries, which have demonstrated the "economic miracle".

Let us also remember the words of Pope John Paul (2001): "a culture that no longer has a point of relevance in God loses its soul and loses its way, becoming a culture of death. Detached from their Christian origins, these models are often inspired by an approach to life marked by secularism and practical atheism and by patterns of radical individualism". Let us add to them the words of Friedrich List, referenced by D.S. Lvov: "There is no world of Wealth! The concept of the world can only be spiritual or alive... How can we talk about the world of minerals, for example? Eliminate the spiritual basis and everything that is called 'wealth' will become a lifeless substance. Remember what happened to the treasures of Carthage and Tir, to the wealth of Venice palaces when the spirit had gone from these heaps of stone?" (Lvov, 2001, p. 49).

\section{COMPARING DIFFERENT TYPES OF RATIONALITY}

Earlier we underlined that everyday rationality is not the same as the rationality in economic theory. However, there are different types of rationally, say instrumental (Winter, 1986), procedural (North, 1990) and institutional (Yerznkyan, 2002).

Two main rationality types are postulated in economic theory - instrumental and procedural. The former has been developed in neoclassical theory; the latter in institutional and the like theories. The instrumental rationality postulate assumes that the players "posses information necessary to evaluate correctly the alternatives and in consequence make choices that will achieve the desired ends" (North, 1990, p. 108). In accordance with the assumptions of the procedural rationality postulate the players "are incompletely informed, devise subjective models as guides to choices, and can only very imperfectly correct their models with information feedback" (ibid). The former postulate is appropriate to the world with low or negligible transaction costs, the latter - with high costs of transacting. 


\section{Comparative Characteristics of Different Types of Rationality}

\begin{tabular}{|c|c|c|c|}
\hline & Instrumental rationality & Procedural rationality & Institutional rationality \\
\hline 1 & $\begin{array}{l}\text { The economic world is reasonably } \\
\text { viewed as being in equilibrium }\end{array}$ & $\begin{array}{l}\text { There is not one equilibrium, but } \\
\text { multiple equilibria }\end{array}$ & $\begin{array}{l}\text { The equilibrium in the economic } \\
\text { world is relative, not absolute, and } \\
\text { depends on institutional space }\end{array}$ \\
\hline 2 & $\begin{array}{l}\text { Individual economic actors re- } \\
\text { peatedly face the same choice } \\
\text { situations or a sequence of very } \\
\text { similar choices }\end{array}$ & $\begin{array}{l}\text { Although individual actors face } \\
\text { many repetitive situations and can } \\
\text { act rationally in such situations, } \\
\text { they also are confronted with many } \\
\text { unique and nonrepetitive choices } \\
\text { where the information is incomplete } \\
\text { and where outcomes are uncertain }\end{array}$ & $\begin{array}{l}\text { Individual actors are institutional. } \\
\text { They face both the same/similar } \\
\text { and unique/nonrepetitive choice } \\
\text { situations. In any case their choice } \\
\text { is - explicitly or implicitly - insti- } \\
\text { tutionally conditioned }\end{array}$ \\
\hline 3 & $\begin{array}{l}\text { The actors have stable preferences } \\
\text { and thus evaluate the outcomes of } \\
\text { individual choices according to } \\
\text { stable criteria }\end{array}$ & $\begin{array}{l}\text { Although relative prices changes } \\
\text { account for many apparent changes } \\
\text { in preferences, the stability issue is } \\
\text { not so easily dismissed. Not only } \\
\text { do anomalies show up at the dis- } \\
\text { aggregated level at which psycho- } \\
\text { logical research has been con- } \\
\text { structed, but certainly historical } \\
\text { evidence suggests that preferences } \\
\text { over time change }\end{array}$ & $\begin{array}{l}\text { The actors' preferences are prede- } \\
\text { termined by institutions. They } \\
\text { choose not what they want but } \\
\text { what they think they should want, } \\
\text { even if they do not give account in } \\
\text { this }\end{array}$ \\
\hline 4 & $\begin{array}{l}\text { Given repeated exposure, any in- } \\
\text { dividual actor could identify and } \\
\text { would seize any available oppor- } \\
\text { tunity for improving outcomes } \\
\text { and, in the case of business firms, } \\
\text { would do so on the pain of being } \\
\text { eliminated by competition }\end{array}$ & $\begin{array}{l}\text { Actors would certainly like to im- } \\
\text { prove outcomes, but because of } \\
\text { possible poorness of information } \\
\text { feedback the actor cannot identify } \\
\text { better alternatives }\end{array}$ & $\begin{array}{l}\text { The actor's rationality is bounded } \\
\text { by his cognitive abilities and com- } \\
\text { putational possibilities, but his ob- } \\
\text { jective settings, viewpoint and be- } \\
\text { havior are institutionally natured }\end{array}$ \\
\hline 5 & $\begin{array}{l}\text { Hence no equilibrium can arise in } \\
\text { which individual actors fail to } \\
\text { maximize their preferences }\end{array}$ & $\begin{array}{l}\text { Competition may be so muted and } \\
\text { the signals so confused that ad- } \\
\text { justment may be slow or misguided } \\
\text { and the classic evolutionary conse- } \\
\text { quences may not obtain for very } \\
\text { long periods of time }\end{array}$ & $\begin{array}{l}\text { Non-competitive behavior situa- } \\
\text { tions are possible. Adjustment of } \\
\text { actors may have institutional ex- } \\
\text { planation }\end{array}$ \\
\hline 6 & $\begin{array}{l}\text { Because the world is in approxi- } \\
\text { mate equilibrium, it exhibits at } \\
\text { least approximately the patterns } \\
\text { employed by the assumptions that } \\
\text { the actors are maximizing }\end{array}$ & $\begin{array}{l}\text { The condition of the world } \\
\text { throughout history provides over- } \\
\text { whelming evidence of much more } \\
\text { than simple rational non- } \\
\text { cooperative behavior }\end{array}$ & $\begin{array}{l}\text { Being rational, economic agent is } \\
\text { able to act emotionally and irra- } \\
\text { tionally. These actions can be ex- } \\
\text { plained by institutional field affect- } \\
\text { ing }\end{array}$ \\
\hline 7 & $\begin{array}{l}\text { The details of the adaptive process } \\
\text { are complex and probably actor } \\
\text { and situation specific. By contrast, } \\
\text { the regularities associated with } \\
\text { optimization equilibrium are } \\
\text { comparatively simple; considera- } \\
\text { tions of parsimony, therefore, dic- } \\
\text { tate that the way to progress in } \\
\text { economic understanding is to ex- } \\
\text { plore these regularities theoreti- } \\
\text { cally and to compare the results } \\
\text { with other observations }\end{array}$ & $\begin{array}{l}\text { The behavioral assumptions of } \\
\text { economists are useful for solving } \\
\text { certain problems. They are inade- } \\
\text { quate to deal with many issues con- } \\
\text { fronting social scientists and are } \\
\text { the fundamental stumbling block } \\
\text { preventing an understanding of the } \\
\text { existence, formation, and evolution } \\
\text { of institutions }\end{array}$ & $\begin{array}{l}\text { The behavioral assumptions of } \\
\text { New Classical Economics must be } \\
\text { re-regarded taking into the account } \\
\text { the achievements of Institutional } \\
\text { Economics. Behavioral socio- } \\
\text { economic models must be as sim- } \\
\text { ple as possible but not simpler }\end{array}$ \\
\hline
\end{tabular}

Source: (Yerznkyan, 2005, pp. 6-7), based on (Winter, 1986, p. S429; North, 1990, p. 24; Yerznkyan, 2002, pp. 220-221). 
An instrumentally acting homo economicus, as well as a procedurally behaving homo psychologicus, play their roles as orators. They may evolve to the actor stand. In fact the homo psychologicus has much more chances to reach the actor's position than his economic colleague. Let us present comparison of their types (Yerznkyan, 2005).

\section{NATIONAL DIFFERENCES}

To illustrate the possibility of transferring national differences, in (Yerznkyan, 2013a,b) a five-point distribution of countries is proposed according to the descending role and significance of the market in them: the limiting case of market transactions is 5, USA 4, Germany - 3, Russia - 2, Japan - 1, non-market interactions - 0 . The propensity to market interaction, or predisposition to transactions, can be reflected as: $1 ; 0.8 ; 0.6 ; 0.4 ; 0.2$ and finally 0 respectively. The types of real countries with poles are not identifiable intentionally, since in reality there is no other repressive of one component, and they co-exist with one degree of domination or another. The fact is that in any country, with a certain generality of national inclination, regional, confessional, ethno-cultural and other differences may manifest themselves (Yerznkyan, Gassner, 2018, p. 134-135).

Take, for example, the United States where there are at least three subcultures coexist in the US - political culture-individualistic or individualistic (individualistic), moralistic (moralistic), and traditionalistic (traditional) (Elazar, 1966). These subcultures can be ranked in different ways: from 1 to 7 , from 1 to 9 . If one evaluates citizenship-oriented policies as 1 , and business stimulation policies as 7 , subcultures on a linear scale are arranged as follows: moralistic (1) - individualistic (4) - traditionalist (7). Between these pure states there can be subcultures-hybrids, when considering the form of the full picture: I (1), M/I (2), I/M (3), I (4), I/T (5), T/I (6), and, finally, T (7) (Boeckelman, 1991, pp. 53-55).

Another example: Italy after 1970s institutional changes, when the central government established 15 regional governments (Yerznkyan, Gassner, 2018, p. 135). And although all the regions had to function more or less in a single key and come to similar results, everything turned out differently: the reason was the deep differences between the central-northern and southern regions which date back centuries (Putnam et al., 1993). Regions in which the institutions of free cities (free cities) - with the beginnings of participative democracy, political organization, providing their citizens with public goods, etc. were developed in the Middle Ages - were more advanced in the sense of civil and cooperative behavior of their citizens, whose culture was transmitted from generation to generation (Alesina, Giuliano, 2013, p. 2).

\section{CONCLUDING REMARKS}

For an adequate description of national specificity, it is necessary to take into account, after Francis Fukuyama, genetic (in the form of propensities or predispositions) and cultural factors (fixed by means of the learning mechanism) factors (Fukuyama, 1999). National specificity is superimposed on genetics: on the whole, Western civilizations with their 
inherent two-valued logic of thinking and the dominance of open access orders in society are more prone to economic exchanges - transactions, while Eastern civilizations, with their multi-valued logic and limited access orders, on the contrary, are more prone to social exchange processes - interactions. It is about propensity (possibility or probability), and not about certainty: Western people in certain circumstances may prefer social markets to economic ones, and vice versa - people in the East can give preference to economic markets over the social ones. We emphasize that in this context the concepts of the West and the East are rather conditional: their features can be evident in Russia as well, which is characterized by a high degree of regional and, additionally, an individual-personal differentiation (Yerznkyan et al., 2017).

The relevance of national specificity should be taken into account in the strategy of transition as the gradual and radical development processes depended on the internal systems of genotypic regularities, which include the conservative and liberal lifestyles, their change and unity. As for Russia, its genotype mutations, characterized by the excessive dominance of conservatory order, need to be eliminated. The process of elimination could be done through an evolutionary transition strategy, assuming both the transformation of the old order and the gradual construction of genotypic economic models. Institutional trajectory of modernization, for example, could start with the «top» level of the existing features of economic systems and be concluded with the consideration of the general genotypic regularities of the global economic system, which does not deny the cultural and socio-economic features of the countries and regions (Arkhipov et al., 2015).

Turning to the experience of developed countries, one can find striking differences between what they had and what they have to offer as a role model. Historical experience testifies the second point of view (first development, then institutions), however the attempts to prove - consciously or not - the rightness of the first point (first institutions, then development) are also happened. There is a definite reason for this: in developed countries, economic development (achieved with existing, though perhaps not permanent, institutions) occurred before major institutional changes, creating a stable basis and opening the way for the modernization of institutions relevant to the socioeconomic dynamics of these countries. In any case, as analysis of approaches to institutions and development shows, «one can not view institutions as an unconditional prerequisite for development - without reference to the specifics of the historical path of development, established institutions and many other factors of the social, cultural, organizational, political, economic nature of a particular country» (Yerznkyan et al., 2014, p. 29).

\section{REFERENCES}

Alesina, A., Giuliano, P. (2013). Culture and Institutions. NBER Working Paper No. 19750. Cambridge, MA, 67.

Arkhipov, A.Y., Yerznkyan, B.H., Martishin, E.M. (2015). Anatomy of the 'Economic Miracle. European Research Studies, vol. XVIII, issue 3, pp. 7-20. 
Boeckelman, K. (1991). Political Culture and State Development Policy. PUBLIUS: The Journal of Federalism, vol. 21, no. 2, pp. 49-81.

Boyd, R., Richerson, P.J. (1985). Culture and the Evolutionary Process. Chicago: University of Chicago Press.

Dementiev, V.E. (2004). Doverie - factor funktsionirovaniia i razvitiia sovremennoi rynochnoi ekonomiki. Rossiiskii ekonomicheskii zhurnal, no.8.

Elazar, D.J. (1966). American Federalism: A View from the States. New York: Harper \& Row.

Fukuyama, F. (1999). The Great Disruption: Human Nature and the Reconstitution of Social Order. Free Press, New York.

Glaziev, S.Yu. (2008). Nravstvennye nachala v ekonomocheskom povedenii i razvitii - vazhneishii resurs vozrozhdeniia Rossii, in Ekonomika i obshchestvennaia: neosoznannoe vzaimovliianie. Nauchnye zapiski i ocherki ( ed. O.T.Bogomolov). Moscow: INES.

Goldschmidt, N., Remmele, B. (2005). Anthropology as the Basic Science of Economic Theory: Towards a Cultural Theory of Economics. Journal of Economic Methodology, vol.12, no.3, pp. 455-469.

Harrison, F. (2001). Editor's Introduction: The Individual as an Ideological Construct. Geophilos, no. 01(1), pp. 3-20.

Kapitza, P.S. (2006). Global Population Blow-Up and After. The Demographic Revolution and Information Society. Hamburg: Global Maarshal Plan Initiative.

Lvov, D.S. (1995). Of the Russian Economic Reforms Scientific Grounding. Moscow: Central EconomicMathematical Institute, Independent Economic Society.

Lvov, D.S. (2001). Rent as Public Revenue: The Strategy for Russia's Breakthrough to the Future. Geophilos, no. 01(1), pp. 48-55.

Lvov, D.S. (2004). Nravsvennaya ekonomika Moscow: Institut ekonomicheskikh strategii.

Makarov, V.L. (2010). Sotzialnyi klasterizm. Rossiiskii vyzov. Moscow: Biznes Atlas.

Martishin, E.M. (2015). Evolutionary-Institutional Grounds of the Modern Reformation, Theory and Practice of Institutional Reforms in Russia, Collection of scientific works ed. by B.H.Yerznkyan, Issue 34. Moscow: CEMI RAS, pp. 20-27 (in Russian).

North, D.C. (1990). Institutions, Institutional Change and Economic Performance. Cambridge: Cambridge University Press.

Pope John Paul (2001). Cultures for a Civilization of Love and Peace. Rome: Vatican, Jan. 1.

Popov, E., Simonova, V. (2015). The Impact of Culture on Inter-Firm Relations in Corporations. Montenegrin Journal of Economics, vol. 11, no. 1, pp. 39-52.

Putnam, R., Leonardi, R., Nanetti, R.Y. (1993). Making Democracy Work. Princeton, NJ: Princeton University Press.

Stiglitz, J.E. (2002). Globalization and Its Discontents. London: Allen Lane, The Penguin Press.

Vinokurova, N. (2016). Russian Semiotics of Behaviour, or Can a Russian Person be Regarded as 'Homo Economicus. In: Facets of Russian Irrationalism between Art and Life: Mystery inside Enigma / Ed. by O.Tobachnikova. Leiden, the Netherlands: Brill Rodopi, pp. 134-159.

Winter, S. (1986). Comments on Arrow and on Lukas. In: Robin M. Hogarth and Melvin W. Reder (eds.), The Behavioral Foundations of Economic Theory // Journal of Business (supplement), vol. 59, pp. S427-S434.

Yerznkyan, B.H. (2002). Concepts of Institutional Man and Institutional Rationality. In: Aktualnye problemy upravlenia - 2002. Tezisy dokladov mezhdunarodnoy nauchno-prakticheskoy konferentsii. Vyp. 5 (Moscow: GUU), pp. 218-222.

Yerznkyan, B.H. (2005). Institutional Reality of Socio-Economic Systems and the Concept of Institutional Man. Evolutionary Theory, Innovations and Economic Change. The VI International Symposium on Evolutionary Economics, Pushchino, Moscow region, Russia, September 23-24, 2005. Russia, Center of Evolutionary Economics. CD-ROM, 2005

Yerznkyan, B.H. (2016). The Influence of Culture on the Economic Behavior. Theory and Practice of Institutional Reforms in Russia: Collection of scientific works / Ed. by B.H. Yerznkyan, issue 35. Moscow: CEMI RAS, pp. 78-87.

Yerznkyan, B.H., Delibasic, M., Grgurevic, N. (2014). Institutional Behavior: Theoretical Issues and Practical Realization. Economics of Contemporary Russia, no. 4, pp. 19-30 (in Russian). 
Yerznkyan, B., Gassner, L. (2018). Cultural and Institutional Differences at the National and Regional Levels. International Journal of Economics, Finance and Management Sciences, vol. 4, no. 3, pp. 133-138. DOI: 10.11648/j.ijefm.20180604.11.

\section{Ерзнкян Б.А., Винокурова Н.А. \\ ОБЛАДАЕТ ЛИ НОМО ЕСОNOMICUS НАЦИОНАЛЬНОСТЬЮ?}

В отличие от обычного представления экономического человека в простой рыночной экономике как homo economicus, люди зачастую выказывают нестандартные типы рациональности, не говоря уж об иррациональности, эмоциональности, альтруизме, коммунальных и ищущих членства импульсах via потребительский выбор и т.п. И хотя в экономической теории рациональность поведения homo еconomicus рассматривается образом, отличным от рациональности в повседневной жизни, возникает вопрос: могут ли реальные люди интепретироваться как - более или менее - экономические персоны или имеют ли они национальность вне пределов нарисованной теоретическиой земли - terra economicus. Что касается национальной специфики, она базируется на генетике: в целом западные цивилизации с присущей им двузначной логикой мышления более склонны к экономическим обменам - трансакциям, в то время как восточные цивилизации, с присущей им многозначной логикой - к социальным обменным процессам - взаимодействиям. В то же самое время западные люди в определенных условиях могут предпочесть социальные рынки экономическим, а люди на Востоке могут отдать предпочтение не социальным, а экономическим рынкам. Такое разграничение скорее условное, как условно и формулировка скорее провокативного вопроса о национальности homo economicus.

Ключевые слова: homo economicus, неэкономические факторы, национальная специфика.

JEL классификащия: A12, B40, D21, M12, M14, O15, P00, Z10. 